American Journal of Applied Sciences 9 (10): 1571-1576, 2012

ISSN 1546-9239

(C) 2012 Science Publication

\title{
Belief and Respect in Multicultural Society: Religious Approach in the Globalised World
}

\author{
${ }^{1}$ Syed Shahid Ali, ${ }^{2}$ Atif Suhail Siddiqui, ${ }^{3}$ Mahmud Ahmad, \\ ${ }^{4}$ Mohd Roslan Mohd Nor, ${ }^{3}$ Khadijah Mohd Khambali Hambali, \\ ${ }^{5}$ Mohamad Zaid Mohd Zin, ${ }^{6}$ Ahmad Faisal Mahdi and ${ }^{7}$ Ahamad Asmadi Sakat \\ ${ }^{1}$ Department of Islamic Studies, \\ Faculty of Humanities and Languages, Jamia Millia Islamia, New Delhi, India \\ ${ }^{2}$ Department of Islamic Thought, Imam Mohammad Qasim Alnanawtawi Institute, \\ Darul Uloom Waqf Deoband, 247554, UP, India \\ ${ }^{3}$ Department of Akidah and Islamic Thought, \\ Academy of Islamic Studies, University of Malaya, 50603 Kuala Lumpur, Malaysia \\ ${ }^{4}$ Department of Islamic History and Civilization, \\ Academy of Islamic Studies, University of Malaya, 50603 Kuala Lumpur, Malaysia \\ ${ }^{5}$ Centre for Islamic Thought and Understanding, \\ University Technology Mara, 94300 Samarahan, Sarawak, Malaysia \\ ${ }^{6}$ Faculty of Business Management, \\ Universiti Technology Mara, 94300 Samarahan, Sarawak. Malaysia \\ ${ }^{7}$ Department of Al Quran and Al Sunnah Studies, \\ Faculty of Islamic Studies, Universiti Kebangsaan Malaysia, 43600 Bangi, Selangor, Malaysia

\begin{abstract}
Problem statement: This article begins with an effort to discuss the wisdom of discussing belief and religion in multicultural society in the world. Approach: The article focuses that human beings cannot reach to the entire truth even to the visible or experienced things through their wisdom, so to trace God's existence based on mere intellectual capacity is baseless. The misconception regarding the unity of religions or religious pluralism is also discussed in this article. The article is written in the view of solidarity of entire humanity with the following of one eternal religion, as well as examines Islam's major role as being the religion of God. Results: This article finds that revelation is needed beyond the human intellectual capacity. God guides humanity through the revelation on those matters, which are beyond human intellect. The concept of one religion, adhering to the teachings from God directly should be the central idea of human intelligence. Conclusion: The article finds that Islam has answered those questions, i.e., the God as a Creator, revelation, resurrection and the responsibility of human being as the most blessed creation of God. These questions are often raised in the mind of a common human being-a believer in God and often in the search of truth.
\end{abstract}

Key words: Belief, intelligence, God, religions, multicultural society, experienced things, human intellect, needed beyond

\section{INTRODUCTION}

Among every faculty that man has been bestowed with, one of the best is "Intelligence" (Gottfredson, 1997). But, this intelligence is not perfect or absolute (Collins, 2009). Spencer has clarified, "absolute cannot in any manner or degree be known in the strict sense of knowing" (Spencer, 1970) because of, according to John Caird, "inherent incapacity of human intelligence to know the Absolute" (Caird, 1988). Intelligence can't work beyond a particular frame of time and space. For instance, the concept of hereafter or akhirah almost in all religions is beyond our intellectual capacity. Those who wish to test this concept based on their intellect, they deny the existence of akhirah. Such perceptions cannot be understood by our intellect. Human intelligence can never perceive a circle without a center and a triangle without an angle. It cannot visualize a fourth direction

Corresponding Author: Syed Shahid Ali, Department of Islamic Studies, Faculty of Humanities and Languages,

Jamia Millia Islamia, New Delhi, India 
except length, width and depth. Therefore, the concepts, which are beyond center, angle and length, cannot be understood by mere human intellect.

In fact, intelligence is so restricted that it cannot recognize anything unusual. For instance, Hammad sang a song that smelt like rose, or the color of this perfume is blue. Moreover, human intelligence is not able to comprehend all things of the past, present and the future (Collins, 2009). It is so limited that it cannot even understand the reality of man - i.e., Spirit. It is also unable to comprehend completely the visible and known beings, for instance, the universe. What was before universe? Where does it exist? What is beyond the universe? If universe is supposed to be eliminated what will happen after it? When was the beginning of time and when is the end of time? These are such questions, which are beyond the human imagination and his intellectual capacity.

A person ponders over his existence and reflects on the ultimate questions of his life. He arrives at the conclusion that there are two options: first, to believe in a Creator or second, not to believe in a Creator (Chopra, 2000).

Now, human intelligence recognizes that almost everything in the world (pen, copy, table, chair, car, airplane) has a creator, so why would not man, who is more advanced and sophisticated, have a Creator? (Arberry, 1951; Penelhum, 1971; Schrader, 1970). Although, God's existence is the central idea of theism and beliefs of all religions but it is beyond the human imaginary capacity as God's existence cannot be "defined in terms which are intelligible to reason" (Ayer, 1952).

Now, our intelligence reflects more and arrives at two subsequent options-One, Creator is single or two; there exist more than one Creator. Here, intelligence compares following situations with more than options each-simultaneously, a country with a Head of State or a country with two Heads of State, a class with a teacher or a class with three teachers and a car with a driver or a car with four drivers. It reaches the conclusion that the first option in each of the situations makes the system smooth, whereas the second brings chaos. Thus, the second finding of intelligence is that man has only one Creator (Qur'an, 21: 22) and is inherent in human nature (Qur'an, 6: 41).

The intelligence further contemplates and again finds two options: First; man should establish contact with his Creator and learn the aim of his life. Or second; the Creator should contact man and furnish him with the knowledge as to why He created man? At this juncture, human intelligence draws the conclusion that the first option is impossible for man as he has no source or means to contact his Creator. In addition, if he does try to define the Creator based on his limited intellect and instinct the intellectual error will vitiate (Caird, 1988) the true identity of God. Therefore, the second option is possible and it is rather just and fair that it should be so.

The Creator is obviously more powerful than His creation, so He should establish contact with man and inform him about the aim of his existence. Consequently, intelligence draws the conclusion that 'it is the Creator who must contact man'.

On further contemplation, human intelligence again stands at two crossroads: one, the Creator should contact all people individually and inform everyone about Him and His Plan of Creation for man. Second, the Creator should make contact with some chosen people and disclose to them His plan for man and then assign the duty to these select people to deliver His message to all human beings.

At this point, all faiths and religions believe that this mortal life is an ordeal for each human being (Mohapatra, 1985; Smart, 1984; (Bible, 3: 10-12, 1: 810, 4: 6-12)). Our intellect senses that if the Creator has made the worldly life of man as a test and trial for him, then $\mathrm{He}$ should not adopt the first means of communication. This is because it would provide surety of the existence of the Creator, hereafter and retribution. Thus, the question paper would leak out before the examination, rendering it useless. It would also curtail the freedom of choice and free will granted to man to believe in God or not. On the other hand, if the Creator would adopt the second option, the world would be an example of a fair examination (Qur'an, 4:166-167).

Additionally, God would also have fulfilled His responsibility to inform some people about His message and make them a means to convey to the people their aim of existence (Qur'an, 42: 51). Hence, the choice to believe in God or not would remain in the hands of man and the option of 'obeying God without seeing' would also be in his control.

Thus, the intelligence reaches the fourth conclusion that; 'the Creator contacted some people (Prophets) and revealed His message to them that consisted of His scheme for man. He gave them the responsibility to convey His message to all the people. So, the worldly life became an examination for man and he received the message and also got the freedom to obey or reject (Qur'an, 76: 03).

Further, the intelligence also arrives at the fifth conclusion that 'the search for God's Messenger' must be made. Here, intellect starts investigating the people who claimed that they received God's message and are His Messengers. Now, intelligence critically assesses and investigates these claimants and their message. 
In this regard, the intellect tests the life of the messenger and his message according to two parameters: first, Historical Credibility, second, Harmony between God's message and human nature, because God is the Creator of man as well as the Giver of the message, so no contradiction must be found therein.

After thorough investigation, human intelligence reaches the sixth and final conclusion that now it must 'follow the message of God given by the Messenger' without any further questioning or doubt, i.e., total obedience.

Obey-one: Few common sayings-All religions are right" and "All religions are one"-are nothing but myths. It is absolutely impossible to follow all religions at the same time. All religions, of present time, are different in their very nature and teachings. Had they been the same in essence, it might have been possible to follow all of them in unison. Since it is not so, it becomes virtually impossible to act upon all the teachings of all the religions at a time.

For example, the Hindu religion gives extraordinary significance to wealth; there is even a Goddess of wealth (Lakshmi), who is worshipped (Noss and Grangaard, 1999; Jayram, 2012). But Christianity condemns superfluous wealth (Bible, 10: $23 ; 16: 13)$.

Jainism (Digambara Sect) considers nakedness as the highest virtue for sages (Gopalan, 1973; Tobias, 1991). However, Islam strictly commands covering the body parts (Quran, 7: 26; 24: 30-31; 33: 59).

The Sikh religion condemns and prohibits cutting the hair of any part of the body (Simmonds, 1992). Contrastingly, Buddhism prefers shaving the hair of the head, beard and moustache; rather even makes it obligatory for Buddhist monks (Harvey, 2000).

Hinduism does not permit divorce and doesn't promote widow-remarriage (Fuller, 2004), but Judaism and Islam allow it.

Few sects in Christianity like Latin Rite Catholic Church and some Eastern Catholic Churches, do not support clerical marriage and banned it for priests. But Islam recommends it for every Muslim including clergy (Quran, 2: 187; 16:72; 24: 32; 30:21).

Buddhism embraces monastic life as the highest virtue (Khantipalo, 1984); however Islam condemns it and prefers a balanced social life. Similarly, in Jainism, the best path for a sage is to voluntarily avoid eating and drinking and embrace death, but Islam prohibits the same.

Belief in the statements, "All religions are right" and "All religions are one" has two logical implications:

Firstly, God works uselessly: At first He gave one religion; Hinduism, after that second; Buddhism, followed by the third; Christianity and afterwards the fourth; Islam, so on and so forth.

Secondly, God intends to develop enmity between mankind, He permits Muslims to be non-vegetarians, but prohibits it for the Buddhists. He prohibits 'Jhatka' (Singh, 1994) meat for the Jews and Muslims but make it strictly obligatory for the Sikhs.

When any follower of a religion claims that he believes that all the religions are right, he is a hypocrite and a liar. If this be his belief, why is he not a Hindu, or a Christian, or a Buddhist, or a Muslim? In fact, few similarities of religions misguide for so called unifications of religions. For instance, all religions encourage honesty and denounce dishonesty, promote truth and condemn lies, each religion prohibits contradiction of words and deeds, everyone is a supporter of justice and peace.

As far as the religious beliefs, actions and faiths are concerned, the slogan "All faith and creeds are correct", cannot be considered a realistic and honest approach. In fact, the sole honest, practical, realistic policy is to say "Obey One Religion" (Karanjkar, 2012).

According to the Qur'an, all the present-day religions can be placed into two groups: Preserved Religions and Non-Preserved Religions.

A religion, in which the message of God is intact in its original shape till today i.e. language and content, belongs to the first category. On the contrary, a religion, which could not preserve the original message of God, due to forgetfulness or fabrication, comes under the second category (Quran, 3: 19; 42: 14-13; 45:17 \& 98:4).

Today, Islam is exclusively the only religion that belongs to the first category of 'Preserved Religions' (Qur'an, 3: 85 and 15: 9). In Islam, the message of God is absolutely and accurately preserved just as it was revealed 1400 years ago. Till today, nobody can prove a minor change in the text of Qur'an (A'zami, 2003).

God gave only one religion for the success of man in the worldly life and the hereafter (Quran, 42:13). The first human being and Prophet, Adam, presented the teachings of religion. God is one, the worldly life is temporary and a test \& trial for man. Life after death is eternal and Man will be rewarded or punished for his deeds committed in the world in the form of Paradise or Hell (Qur'an, 2: 37-39). The religion of God is eternal, therefore, for reminding the message to the people the chain of prophets continued until the humanity reached the zenith of mental and intellectual height. Mohammad came as the last of the messengers with the last of the commandments.

In ancient times, the means of communication and transportation were very limited and undeveloped. Mobility of the people was minimal. As a result, one 
Prophet came for one region and others for other areas. This process of different prophets coming to give the message of God continued till the advent of Muhammad (peace be upon him), the last in the line of prophets. He also presented the same teachings but in their pure form. Thus, the message of God or all the original teachings presented by different prophets over the time culminated in the shape of Islam.

From Adam to Muhammad, every prophet brought the same religion i.e., the religion of God (Din) except for one difference.

God did not protect the teachings of previous revealed books. For instance, in Bible God put the responsibility of protection on the shoulders of the believers (Bible, 22: 18, 19) while Qur'an says that God protects Qur'an Himself from any abrogation (Qur'an, 15:9). Therefore, the final message of God, presented by Muhammad (the Qur'an) was, is and will be under the protection of God. He Himself took the responsibility to keep it safe and intact. As a result we see that no one has been able to change it till today. Approximately 1400 years have passed, but the Qur'an is available in its original and pure form. It is a clear proof of God's protection and power. There is no religious scripture other than Qur'an, which makes the similar claim of Divine protection from abrogation and human deceit.

The message of God was itself more important than the prophets themselves. After the arrival of the final and the last message of God, there stands no need for any other message (because all the messages were the same and the final message "the Qur'an" has the protectioncover of God. The chain of prophets concluded with the coming of Prophet Muhammad. Since then and till the end, no new prophet or message will come in this world. The Qur'an is available in its pure form and is most sufficient for the guidance of man.

Communicate-yours: According to the belief of the Muslims, Islam is the only existing religion of God (Qur'an, 3: 19; 5:3). God clearly announces in the Qur'an that He will not accept any religion except Islam (Qur'an, 3:85). He commands that a party from the believers must invite mankind to good, enjoining what is right and forbidding the wrong ( Qur'an, 3:104). Therefore, every Muslim bears in mind the concept of Da'wah (invitation or call to the belief in Allah). According to Adams (1977), "By its very form [as a verbal noun] it conveys a feeling of action and ongoingness... One who thoughtfully declares 'I am a Muslim' has done much more than affirm his membership in a community (Adams, 1977).

Da'wah is to communicate the message of the Prophet Muhammad to all the people of all times. It is, in fact, a divine task. That is why the Qur'an has called it 'Nusrat' of God i.e., helping the Almighty (Qur'an, 3:52). According to the Qur'an, Da'wah means to make oneself Nasih and Amin i.e., an honest and sincere well-wisher of all (Qur'an, 7:68). In this modern days, da'wah could also involve dialogue among nations as well as civilizations (Moghimi, 2005). This is especially to address the issue of living in harmony without religious fundamentalism (Baldwin, 2012).

The highest good, which should be shared, is faith. Any Muslim harboring real love and true well-wishing for his fellow-beings will naturally make humble effort for the work of Da'wah. To enjoin the right and forbid the evil is in essence the result of human love (Qur'an, 3:114).

God Himself assigned the believers the duty of Da'wah. He says that theirs is the best of nations, on the condition that they invite to God (Qur'an, 3:110).

Following Islam means ensuring success in the worldly life as well as in the life hereafter. It is impossible for a true Muslim not to invite others to Islam, if he truly believes and is a genuine well-wisher of mankind. Not inviting others to his path is counted as a sin for a Muslim. Da'wah work is an obligatory duty for each and every Muslim. After identifying the right path or guidance, it is selfishness not to share it.

Actually, Da'wah means invitation to Allah or call to Allah. It is, in fact, an effort to connect the people with God. All the Messengers of God came in this world to inform mankind about the creation-scheme of God regarding human beings; i.e., the aim of life, the right path for life, details of life-hereafter.

It is literally an unsaid moral pact among all mankind that when a person goes towards harm, others try to stop him with their all power and means. When saving the temporary body is considered a human value, why should saving the spirit from eternal hell not be considered the highest virtue? The Qur'an makes Da'wah work obligatory on every follower of Islam through Prophet Muhammad (Qur'an, 22: 67, 41: 33).

The base of Da'wah is wishing well for all. Promoting good in the society is also a main objective of Da'wah. The Qur'an, however, doesn't just promote the concept, but also gives the technique for performing it. Da'wah work should be done with good intention, sincerity and wisdom.

Da'wah work must be performed in the best manner of conversation (Quran, 20:44, 3:159). The best character or side of the individual should be exhibited (Qur'an, 41:34, 23:96). The best method of dialogue ought to be adopted (Quran, 16:125, 29:46). Taunts, comments and abuse must be avoided at all costs (Qur'an, 6:108). It should be in the form of dialogue, not in the orthodox style of debate (Qur'an, 
22:67-69). The gist of the discussion should gradually move from similarities to dissimilarities (Qur'an, 3:64). It must not only cover others' but near and dear also (Quran, 26:214, 6:74).

It must be borne in mind that self- reform and inviting others to Islam is a parallel process.

\section{CONCLUSION}

The presentation of Islam to non-Muslims should be done after his direct or indirect consent; otherwise it might be considered the breach of privacy. After listening and pondering over the message of Islam, the listener is free to accept or reject it.

There is no compulsion in the matter of religion (Qur'an, 2: 256, 25: 57, 73: 19, 74: 55, 76: 29). Disagreement should not lead to discord and the preacher must respect other's decision (Quran, 109:6).

Abusing other's concept of religion is not an amiable way to reach a conclusion (Quran, 6:108). The preacher continues to respect his opinion and his cooperation remains continued in every other matter e.g., social, political, economic, educational, moral. 'Dissent with respect' is a Qur'anic policy after presenting Islam. The preacher will respect all religions even if they do not conform to what we believe.

A Muslim wants to see everyone as a Muslim. A Christian wishes to see the whole world turn into Christianity. A Buddhist desires to see every man as a Buddhist.

In fact, this desire is not a bad thing from the perspective of the adherents of other religions too. True and selfless well wishing is behind this emotion. Inviting others towards their religion is compulsory in many religions besides Islam. They all also want to save others from eternal loss according to their own view. This is a very precious point where a Muslim preacher can stand together with the preachers of other religions. This gives more appealing and substantial opportunity to the preachers of Islam to convey their message to the non-Muslims.

If the society does not accept the right of preaching and propagation of faith, the obligatory nature of this responsibility naturally creates suffocation in the minds of the followers. It will generate guilty conscious and the terrible result of this suppression will be very harmful for the individual and the society. 'Obey one religion, communicate your religion and respect all religions' is, as we may conclude, the only feasible and realistic formula in this contemporary, globalized world. This policy can undoubtedly bring peace in this world on the religious level.

\section{REFERENCES}

Adams, C.J., 1977. A Reader's Guide to the Great Religions. 2nd Edn., Free Press, New York, ISBN10: 0029002400, pp: 521.

Arberry, A.J., 1951. Avicenna on Theology. 1st Edn., John Murray, London.

Ayer, A.J., 1952. Language, Truth and Logic. 2nd Edn., Dover Publications, New York, ISBN-10: 0486200108, pp: 160.

A'zami, M.M., 2003. The History of the Qura'nic Text from Revelation to Compilation. 1st Edn., AlQalam Publishing, Alberta, ISBN-10: 1926620097, pp: 448.

Baldwin, E.D., 2012. Religious Dogma without Religious Fundamentalism. J. Soc. Sci., 8: 85-90. DOI: $10.3844 /$ jssp. 2012.85-.90

Caird, J., 1988. An Introduction to the Philosophy of Religion. 1st Edn., AMS Press, New York, pp: 343.

Chopra, D., 2000. How to Know God.1st Edn., Ebury, London Rider, ISBN-10: 140902220X, pp: 320.

Collins, G.P., 2009. Within any possible universe, no intellect can ever know it all. Sci. Am. Mag.

Fuller, C., 2004. The Camphor Flame: Popular Hinduism and Society in India. 1st Edn., Princeton Princeton University Press, Princeton, ISBN-10: 069112048X, pp: 343.

Gopalan, S., 1973. Outlines of Jainism. Halsted Press, 1st Edn., New Delhi Wiley Easter, ISBN-10: 0852263244, pp: 214.

Gottfredson, L.S., 1997. Foreword to "intelligence and social policy". Intelligence, 24: 1-12.

Harvey, P.B., 2000. An Introduction to Buddhist Ethics. 1st Edn., Cambridge University Press, Cambridge, ISBN-10: 0521556406, pp: 498.

Jayram, V., 2012. Purusharthas or the four aims of human life.

Karanjkar, M., 2012. Unification of religions.

Khantipalo, B., 1984. The buddhist monk's disciplines. kandy: The buddhist publication society.

Moghimi, E., 2005. Active Center of Islamic Dialogue Civilizations. J. Soc. Sci., 1: 184-187. DOI: 10.3844/jssp.2005.184.187

Mohapatra, A.R., 1985. Philosophy of Religion. InterVarsity Press, Downers Grove, pp: 192. ISBN-10: 0877843430

Noss, D.S. and B.R. Grangaard, 1999. A History of the World Relgions. 1st Edn., Prentice-Hall Inc., New Jersey, ISBN-10: 0136149847, pp: 655.

Penelhum, T., 1971. Divine Necessity. In: The Philosophy of Religion, Mitchell, B., (Ed.), Oxford University Press, London, pp: 179-190. 
Schrader, D.E., 1970. The Antinomy of Divine Necessity. Int. J. Phil. Rel., 30: 45-59.

Simmonds, D., 1992. Believers All: A Book of Six World Religions. Nelson Thornes, Walton-onThames, pp: 144, ISBN-10: 0174370571

Singh, I.J., 1994. 15 Food Taboos in Sikhism. In Sikhs and Sikhism: A View with a Bias. Michigan: University of Michigan, New Delhi, pp: 157. ISBN-10: 8173040583
Smart, N., 1984. The Religious Experience of Mankind. 3th Edn., Scribner, New York, pp: 634. ISBN-10: 0024121304

Spencer, H., 1970. First Principles. In J. Caird, An Introduction to the Philosophy of Religion. AMS Press Inc., New York, ISBN: 0404013635.

Tobias, M., 1991. Life Force: The World of Jainism. 1st Edn., Asian Humanities Pr, ISBN-10: 089581899X, pp: 128. 